\title{
Exploring the perspectives of integrated reporting for future research opportunities
}

\author{
Chirața Caraiani ${ }^{\mathrm{a}}$, Camelia I. Lungu ${ }^{\mathrm{a}, 1}$, Alina Bratu \\ and Cornelia Dascălu ${ }^{\mathrm{a}}$ \\ ${ }^{a}$ Bucharest University of Economic Studies, Romania
}

\begin{abstract}
This paper investigates the perspectives of integrated reporting as an emerging field in mainstream academic literature. The current state of research and its development are explored by using the Structured Literature Review (SLR) method on publications indexed in Clarivate Analytics' Web of Science. An analytical framework is designed for applying the coding procedure. The findings suggest an evolution of integrated reporting research from the phase of spreading awareness regarding the new reporting paradigm towards an impact analysis phase. The accounting and audit journals are noted to have greatly contributed to the shift of IR literature towards studying the integrated reporting as a reporting practice. A further purpose is to examine newly developed research interest in integrated reporting and to establish future paths to be followed. Future research might bring to discussion possible links between integrated reporting, governance and integrated thinking. The complex interrelationships influencing the companies' ability to create value for the multi-stakeholders need to frame the practice-oriented research.
\end{abstract}

Keywords: Integrated reporting, structured literature review, IR literature, metaanalysis

JEL codes: M14, M41

${ }^{1}$ Corresponding author: Department of Accounting and Audit, Bucharest University of Economic Studies; Piata Romana, 6, room 1012; email address: camelia.lungu@ cig.ase.ro 


\section{Introduction}

In the last years, the focus on economic, social and environmental reporting had increasingly become significant, as corporate collapses, the global financial crisis, social and environmental matters, or climate change became current concerns (Haji \& Anifowose, 2017). In order to answer these issues, the organizations had to remodel their corporate reporting practices, transiting from mandatory reporting to voluntary disclosure. This approach is increasing in usage as it provides more relevant information and creates the premises for an improved corporate transparency and accountability (Dumay et al., 2016; Vaz et al., 2016). In this context, integrated reporting is gaining considerable momentum as it sets out to redirect the thinking of corporate actors towards voluntary material disclosure reporting information considered essential for the stakeholders. This contributes to the further integration of sustainability and has consequences on corporate strategic planning and decision-making (Gunarathne \& Senaratne, 2017).

The International Integrated Reporting Council (IIRC) has introduced integrated reporting as the most recent reporting practice that will serve as a replacement to the actual reporting system (Brown \& Dillard, 2014). This emerging corporate reporting initiative addresses the limitations of traditional financial reporting, usually criticized for its great amount of information as well as for the disconnected manner used to present that information (Zhou et al., 2017). Along with IIRC' attempts to globally introduce integrated reporting practices, the academic body started to spread awareness related to this innovative approach to corporate reporting. In recent years, integrated reporting literature has vastly expanded, especially after the IIRC Framework's publication in December 2013. Therefore, leading academic journals have begun to frequently cover this topic and it became an attention attracting subject, especially in accounting research.

The aim of this paper is to investigate the state of integrated reporting as an emerging field in mainstream academic literature as well as to examine the actual condition of this newly developed research interest. In order to study integrated reporting research development, a review of the publications indexed in Clarivate Analytics' Web of Science (formerly known as Thomson Reuters database) was carried out. This database was chosen as the indexed articles are enjoying the widest readership and are the most cited by specialists (Lungu et al., 2016). Therefore, a scientific paper available in Web of Science has a recognized quality and exposure to the international scientific community (Lungu et al., 2009). 
This paper employs a Structured Literature Review (SLR) method (Massaro et al., 2016) which allows to provide insightful and effective findings that are different from the traditional literature reviews. The main reason of adopting a SLR methodology resides the fact that integrated reporting is in its "early stages of development" (Petticrew \& Roberts, 2008: 21 quoted in Dumay et al., 2016), and a small number of specialists could have accumulated sufficient knowledge on this theme to make a valid traditional literature review (Dumay et al., 2016).

In this respect, our paper approaches two research questions, focusing on <IR $>$ literature.

RQ1. How have the integrated reporting field developed in recent years?

RQ2. How and why is the research field changing?

RQ2.1 How global is the integrated reporting research and is there a shift in its perspective?

$R Q 2.2$. What are the best research practices in integrated reporting?

$R Q 2.3$. Is there a connectivity between the criteria of IR frameworks and the focus of IR literature?

This study is not first in line to conduct a comprehensive literature analysis, as reviews on integrated reporting were previously carried out (e.g. Dumay et al., 2016; De Villiers et al., 2014). The previous studies focus on the emergence of integrated reporting literature, analyzing the first stage of this process. This paper does not aim to reconstitute or re-analyze the previous works. The purpose here is to develop new insights based on prior findings and to extend the sample used by the authors in their respective literature reviews, covering the period of time that could not be previously included. Another aim of this study is to identify future research perspectives, based on the literature gaps found in the newest published articles.

The remainder of this paper is organized as follows: Section 2 offers a brief review in order to present the background of integrated reporting and to establish the general state of contemporary literature. Section 3 explains the key methodological aspects of the SRL method, as well as the articles selection process and the analytical framework definition. Section 4 describes the research findings and provides insights on the integrated reporting literature. Section 5 presents the concluding remarks of this study and outlines an agenda for future research as depicted in the analyzed articles. 


\section{Literature review - integrated reporting background}

The topic of integrated reporting is lately enjoying a great amount of global attention from scholars, specialists, managers, organizations, audit firms and mass media. This section analyzes the academic literature in order to explain the background of integrated reporting as well as to document the journey of this practice since its beginnings.

Designing an integrated corporate reporting system is not an area of recent interest and its introduction dates two decades ago. In 1995, John Elkington presented a famous expression "People, Planet and Profit" which became known as the Triple Bottom Line (TBL). The concept was proposed by the author as a method to achieve sustainable development by combining social, environmental and economic disclosures (Dumay et al., 2016). Since then, this model has enjoyed a great amount of notoriety not only among companies but also for consultancy firms and agencies, accounting professions, and even NGOs (Rambaud \& Richard, 2015). The TBL concept was created to change the traditional reporting focus of providing financial information to shareholders towards offering non-financial disclosures, as the company's economic added value was not adequate to create sustainable results (Caraiani et al., 2015). The TBL model has created a solid foundation on which sustainability reporting and research have developed under the inclusive stakeholder view (Gleeson-White, 2014 cited by Dumay et al., 2016).

At country's lever, the South Africa is the first to create in 1994, a Code of Corporate Governance to extend the financial disclosure requirements with social, environmental and governance elements, known as King Report on Governance. The concept of integrated sustainable reporting is introduced subsequently in the second version of the Report. In 2010, the third version of King's Report became compulsory for the companies listed on Johannesburg Stock Exchange, setting South Africa as the first country with mandatory integrated reporting (Dumay et al., 2016).

While the social and environmental reporting practices began to globally expand, policy development became necessary. Voluntary reporting standards and guidelines were created as a way to guide organizations' initiatives to successfully engage in sustainable reporting (Buhr et al., 2014). In this context, the Institute of Social and Ethical Accountability (AccountAbility) and the Global Reporting Initiative (GRI) were among the organizations that developed the most compelling and extensively adopted reporting and assurance standards for social and environmental reporting (De Villiers et al., 2014). 
Undoubtedly, the most prominent standards have been those elaborated by the GRI. This multi-stakeholder cooperation managed to formulate and establish a generally accepted framework for environmental, social and economic reporting (Buhr et al. 2014). One purpose of the social and environmental reporting regulation was to create the basis for enhanced credibility and comparability in the reporting practice. However, as the GRI guidelines started to standardize more and more social, environmental and governance issues, the sustainability reports also became more elaborate and extensive. Apart from these characteristics, further developments and valid evidence need to be addressed to improve corporate policy and practice (De Villiers et al., 2014).

In order to enable an efficient reporting practice, Eccles and Krzus (2010) proposed a first version of integrated reporting by introducing a new concept: One report. This concept claimed to present "financial and nonfinancial information in such a way that shows their impact on each other" (Eccles \& Krzus, 2010: 10). The book advocates the integrated reporting practice by promoting two main reasons as of why organizations should adopt One Report as their external reporting procedure. The first motivation states that this innovative concept is a key element for a genuine sustainability reporting as it enables an improved risk management and it created opportunities to ensure a sustainable society. The second motivation is improved corporate communication and transparency, as the One Report is concise and it can transmit a single message to all stakeholders (Eccles \& Krzus, 2010). The company's holistic perspective is later considered in Eccles and Krzus (2015) advanced proposal for a new concept, that of materiality matrix. The company's performance is seen in the context of value created for each stakeholder (Lungu et al., 2017).

All these initiatives proposed improving measures for the existing corporate reporting practices, but the break out point for integrated reporting was the IIRC's establishment in 2009. Since then, integrated reporting has immediately gained notable importance. Consequently, the IIRC has become the global leading organization in developing policy and practice recommendations in the field of integrated reporting (De Villiers et al., 2014). In addition, integrated reporting has emerged as a key procedure (Chaidali \& Jones, 2017) as the annual reporting processes were unsuccessful in disclosing social and environmental issues in a transparent manner.

The IIRC is a "global coalition of regulators, investors, companies, standard setters, the accounting profession and NGOs" and brings together "the relevant and informed people and organizations" (IIRC, 2013a) involved in corporate reporting. The main purpose of this organization is to elaborate a conceptual framework which enables 
the preparation of a concise, user-centered voluntary report entitled as the integrated report (Cheng et al., 2014). From 2011 to 2014, the IIRC implemented a Pilot Programme, which aimed to build the context for the future conceptual framework (Mio et al., 2016). Additionally, the IIRC used the Pilot Programme with the purpose to generally understand the actual corporate reporting practices (IIRC, 2013b). The pilot program included more than 75 companies and 25 investor bodies. In the first half of 2013, the Consultation Draft was published by the IIRC, with an invitation addressed to any interested party to leave comments and suggestions. In December 2013 the final version of the IIRC Conceptual Framework was published.

Excluding the companies that choose to experiment with integrated reporting in its early stage, South Africa was the first country to require listed companies to provide an integrated report. Specifically, the listed companies on the Johannesburg Stock Exchange were required to adopt integrated reporting practices on a 'comply or explain' basis (Cheng et al., 2014). The South African integrated reporting framework had a greater focus on social, environmental and sustainability issues than the IIRC Framework (De Villiers et al., 2014). The IIRC Framework has received critique on this matter, as it focuses to create "value for investors" (Flower, 2015:1) as opposed to the South African framework.

As rapid development and increasing relevance of integrated reporting are the main drivers for academic literature expansion, this new reporting practice is becoming an established emerging research field. Recently, some studies analyzed and reviewed the relevant literature on integrated reporting, such as De Villiers et al. (2014), Cheng et al. (2014), Dumay et al. (2016), Velte and Stawinoga (2017) and De Villiers et al. (2017) offering useful insights and understandings as well as research agendas useful for the academics involved in this study area.

\section{Research methodology}

\subsection{Research method}

The Structured Literature Review (SRL) method is used for this paper because the 'integrated reporting' is a rather new concept (Dumay et al., 2016), placed by Petty and Guthrie (2000) in the stage of raising awareness of its potential. Although, firstly referred to by IIRC in 2010, previous related concepts existed, as 'integrated sustainability reporting' concept introduced by King II report. By using the SRL method, the premises required to identify research gaps in literature as well as to formulate research hypotheses and find future research paths may be scientifically 
set up. This paper is based on previous works of Dumay et al. (2016), Massaro et al. (2016), Guthrie et al. (2012), and Pisani et al. (2017). Proposed by Massaro et al. (2016), SLR is a method that favors the development of insights and critique related to the status of a knowledge field, through a systematic review of the academic literature.

The SLR approach offers two specific advantages. First, the SLR method is a tool which increases the objectivity of a literature review, as traditional literature reviews are criticized for being too subjective (Petticrew \& Roberts, 2008 cited by Dumay et al., 2016). Nevertheless, the practicality of the traditional literature review cannot be contested, as this is the most common management research technique (Denyer \& Tranfield, 2006), in which the researcher compiles and highlights the key findings of previous scientific literature using a subjective and narrative approach. Moreover, the value of traditional literature research resides in the fact that it is "written by someone with a detailed and well-grounded knowledge of the issue" (Petticrew \& Roberts, 2008:10 quoted in Dumay et al., 2016). Based on this assertion, Massaro et al. (2016) argue that traditional literature reviews could represent sources of compelling insights, nevertheless this depends on the researcher's knowledge of the studied field. The SLR method complements traditional literature reviews, as this concept helps to achieve legitimate results by providing validity to the review's results.

The second advantage of the SLR approach lies in the fact that this method offers alternative techniques for experienced academics to open up new research directions, which would be quite difficult to access using a traditional approach. Thus, the SLR method may become an instrument for experienced researchers to advance new research paths by studying a substantial amount of academic literature (Massaro et al., 2016).

When applying the SLR methodology, Massaro et al. (2016: 771-772) recommends the following ten steps for a rigorous literature review, that were also applied within this paper:

(1) "write a literature review protocol;

(2) define the questions that the literature review is setting out to answer;

(3) determine the type of studies and carry out a comprehensive literature search;

(4) measure article impact;

(5) define an analytical framework;

(6) establish literature review reliability;

(7) test literature review validity; 
(8) code data using the developed framework;

(9) develop insights and critique through analyzing the dataset; and

(10) develop future research paths and questions".

The flexibility of this method resides in the feature that the ten steps need not to be chronologically followed. The researcher has the freedom of adding new criteria as he/she advances through the articles' analysis. Thus, the analytical framework may be reformulated, once the analysis reveals new and significant attributes.

\subsection{Research database}

The focus of this review is on scientifically validated articles that will ensure the validity of the findings and further discussion. Therefore, the selection of the sampled articles referred to those articles published by peer-reviewed academic journals, excluding other types of publications, such as books or conference proceedings. Critically following the ten steps of a SRL (Massaro et al., 2016), the articles were selected from the Clarivate Analytics Database, covering different economic disciplines. From the articles published during the latest eight years, a final sample of 72 articles was established, after the completion of several phases, described as follows.

First, for the literature search, the primary data source is Clarivate Analytics' Web of Science Core Collection, internationally recognized and providing a validated tool for measuring the article impact, the Citation Report. A computer-based examination of the database was performed by searching the title, abstract and keywords of all the journals indexed in this database. The research objective of reviewing the integrating reporting literature limited the starting date at January, 2010. A cuttingdate of $15^{\text {th }}$ of November, 2017 was adopted. All articles referring to concepts as 'integrated reporting', 'IIRC' or 'integrated report' were selected, saved and organized by categories.

Second, the articles' search results were refined. Out of the six main indexed the Web of Science Core Collection is organised in, two main indexes, reflecting the social science research areas were selected: Social Science Citation Index (SSCI) and Science Citation Index Expanded (SCIE). Further, the Web of Science category was considered, to limit the selection only to accounting-relevant research themes. As this study focuses on integrated reporting literature, the selected categories were: Business and Finance, Management, Business, Economics (belonging to the SSCI), and Engineering, Environmental and Environmental Sciences (belonging to the SCIE). Hence, those categories that did not have any relation to the integrated 
reporting research area, such as Medicine General Internal or Oncology were eliminated. Taking in consideration the described criteria, an initial sample of 65 articles published in 24 journals was established.

In order to complete the data set, a manual search on the previously identified journals doubled the computer-based search. The focus was on articles that were not available on the Core Collection. Next, the Clarivate Analytics' Master Journal list was consulted, and the journals' list for the 'Business, Finance' and 'Management' categories were obtained. These categories were chosen based on the inclusion of the most representative academic publications related to the integrated reporting field. Each journal included in these two categories (96 journals for 'Business, Finance' and 198 journals for 'Management') was manually searched for articles, as the probability to identify articles that haven't previously found was quite high. In some cases, the full-text of the articles was analyzed, as the abstract or the keywords did not provide relevant information in order to establish whether the article focused on integrated reporting or not. As a result, seven forthcoming articles were found and included in the data set, which increased the final sample to 72 articles published in 26 journals.

\subsection{The analytical framework}

The next important step in developing the SLR was to define an analytical framework. To develop the framework, criteria previously used by Dumay et al. (2016), Guthrie et al. (2012), Dumay and Garanina (2013), and Broadbent and Guthrie (2008) are referred to, analyzed and verified for suitability for the research questions and sample, presented in sections 1 and 3.2 of this paper. To test and to adapt the details of the final criteria used and of the coding system, an initial framework was applied to a six sample articles, independently, by the four authors. During this pre-coding phase, the criteria and attributes were reviewed, changed or removed and new attributes were added.

As a result, outlined in Table 1, a modified and improved analytical framework was applied for the entire database of 72 articles. Eight different criteria, with three to ten attributes are used to characterize the research articles. Details about the changes, improvements and removals are presented further. Explanations related to the criteria/attributes included in the analytical framework, as well as the rules used in the coding process are illustrated in detail. 
Table 1. Analytical Framework

\begin{tabular}{|c|c|c|c|}
\hline $\mathbf{A}$ & Jurisdiction & $\mathbf{B}$ & Organisational focus \\
\hline A1 & Supra-national/International/Comparative & B1 & Publicly listed \\
\hline A1.1 & $\begin{array}{l}\text { Supra-national/International/ } \\
\text { Comparative - General }\end{array}$ & B2 & Private - SMEs \\
\hline A1.2 & $\begin{array}{l}\text { Supra-national/International/ } \\
\text { Comparative - Industry }\end{array}$ & B3 & Private - Others \\
\hline A1.3 & $\begin{array}{l}\text { Supra-national/International/ } \\
\text { Comparative - Organisational }\end{array}$ & B4 & Public sector \\
\hline $\mathrm{A} 2$ & National & B5 & Not-for-profit \\
\hline$A 2.1$ & National - General & B6 & General/Other \\
\hline$A 2.2$ & National - Industry & & \\
\hline$A 2.3$ & National - Organisational & & \\
\hline A3 & One Organisation & & \\
\hline $\mathbf{C}$ & Location of research \& Authors' affiliation & $\mathbf{D}$ & Data sources \\
\hline$\overline{\mathrm{C} 1}$ & USA/Canada & D1 & Corporate information database \\
\hline $\mathrm{C} 2$ & Australia & D2 & Authors' primary data \\
\hline $\mathrm{C} 3$ & United Kingdom & D3 & Intergovernmental organization \\
\hline $\mathrm{C} 4$ & European Union (UK excluded) & D4 & Corporate website or internal data \\
\hline C5 & South Africa & D5 & Stock index \\
\hline C6 & Asia-Pacific & D6 & Mixed data sources \\
\hline $\mathrm{C} 7$ & Other/Mixed & D7 & Other \\
\hline $\mathbf{E}$ & $\begin{array}{l}\text { Research methodology \& Research } \\
\text { methods }\end{array}$ & $\mathbf{F}$ & Focus of IR literature \\
\hline \multirow[t]{3}{*}{ E1 } & Theoretical & F1 & $\begin{array}{l}\text { External reporting/Sustainability } \\
\text { reporting }\end{array}$ \\
\hline & Commentary/Normative/Policy & $\mathrm{F} 2$ & Auditing and assurance \\
\hline & Literature review & $\mathrm{F} 3$ & Accountability and governance \\
\hline E2 & Empirical & $\mathrm{F} 4$ & Management control/Strategy \\
\hline$\overline{\mathbf{E}}$ & $\begin{array}{l}\text { Research methodology \& Research } \\
\text { methods }\end{array}$ & $\mathbf{F}$ & Focus of IR literature \\
\hline \multirow[t]{4}{*}{$\bar{E} 2.1$} & Qualitative & F5 & Performance measurement \\
\hline & Case Study & F6 & IR in practice - general \\
\hline & Content analysis/Historical analysis & F7 & Value creation/Business Model \\
\hline & Interviews & F8 & Integrated thinking/Capitals \\
\hline \multirow[t]{5}{*}{ E2.2 } & Quantitative & F9 & IR Determinants/benefits \\
\hline & Statistical and econometric methods & F10 & Other (including general) \\
\hline & Survey/Questionnaire & & \\
\hline & Content analysis/Historical analysis & & \\
\hline & $\begin{array}{l}\text { Mixed quantitative } \\
\text { Multiple }\end{array}$ & & \\
\hline
\end{tabular}




\begin{tabular}{|c|c|c|c|}
\hline$\overline{\mathbf{G}}$ & Approaches to IR & $\mathbf{H}$ & $\begin{array}{l}\text { IR Frameworks, models, } \\
\text { instruments }\end{array}$ \\
\hline G1 & $\begin{array}{l}\text { King Report on Governance (IRC of South } \\
\text { Africa) }\end{array}$ & H1 & None proposed \\
\hline $\mathrm{G} 2$ & One Report & $\mathrm{H} 2$ & Applies or considers previous \\
\hline G3 & IIRC pre-2013 Guidelines & H3 & Proposes a new \\
\hline G4 & IIRC, 2013 Guidelines & & \\
\hline G5 & GRI Framework & & \\
\hline G6 & Multiple frameworks & & \\
\hline
\end{tabular}

The Jurisdiction (A) and Organisational focus (B) criteria are adopted from Dumay et al. (2016). The first two attributes composing the Jurisdiction criterion (A1 and A2) are further split into a General, Industry or Organisational setting. The articles that do not have an empirical base such as literature reviews or normative research are coded as 'General' (A1.1 and A2.1), whereas articles analyzing the integrated reporting focusing on an industry (A1.2 and A2.2) or on organizational setting (A1.3 and A2.3) are coded according to their Supra-national or National approach. The case studies referring to a single organization are classified as A3. The second criterion, Organisational focus (B) consists of six different attributes: B1 Publicly listed, B2 Private - SMEs, B3 Private - Others, B4 Public sector, B5 Not-for-profit, B6 General/Other. The articles which did not fall in the B1-B5 categories or did not adopt an organizational focus (e.g. normative research) are coded as General-other.

The Location of research (C) criterion is adapted from Dumay et al. (2016), with changes in the coding process. Whether Dumay et al. (2016) considered the country of the first author when coding the regional focus or the geographical location of the research, we focused on the location of the companies/countries included in the research. The criterion is divided into six countries/regions (Table 1). European Union (C4) is maintained as in Dumay et al. (2016), from which the United Kingdom is excluded, as it is considered separately. A distinct attribute for Australia (previously included in 'Australasia') was added along the coding process. The database has been then revised to illustrate this separate location. The reason for this adjustment is a representative contribution on integrated reporting research in the Australian context. The articles that did not have a specific research location, either empirical articles or articles with an international - organizational focus, are categorized as $\mathrm{C} 7$ Other.

Dumay's et al. (2016) approach interferes with the discussion of the results, as it allows articles to be coded within this category even if they do not have a definite 
regional setting. To overcome this limitation, a specific contribution of this study is the development of a new criterion, emerging from Location of research, namely Authors' affiliation. The category was also used by Pisani et al. (2017). The purpose of this new criteria, having the same attributes as Location of research, allows to present an in-depth discussion on the second research question of the paper, $R Q 2$ How and why is the research field changing. The criterion is used to develop insights regarding the amplitude of the international integrated reporting research. The most engaged locations in integrated reporting research are then compared with the region where the authors are affiliated.

The Data source (D) criterion adapted from Pisani et al. (2017) includes seven attributes. Attribute D1 Corporate information database refers to data sources such as Compustat, Thompson Reuters, GRI Database or Forbes Global 2000 list. In the D2 Authors' primary data are classified the articles using data collected by authors from interviews, questionnaires or surveys. D3 Intergovernmental (or multistakeholder) organization includes data downloaded from the Integrated Reporting Examples Database of the International Integrated Reporting Council. With D4 Corporate website or internal data are coded articles using reports downloaded from the companies' websites or internal documents. Articles using data from stock markets, such as IPO Prospectuses, are coded as D5 Stock index. Finally, in the D6 Multiple sources articles that used 2-3 distinct data sources are included (e.g. Mio et $a l ., 2016$ used as data sources information from interviews, internal documents and field observations) and in the D7 Other category were included studies that did not have a data source.

The next criterion is built on Pisani's et al. (2017) for Research methodology and Dumay's et al. (2016) and Guthrie's et al. (2012) for Research methods employed by the authors of IR research. The Research methodology criterion includes two main attributes: E1 Theoretical (including conceptual articles or literature reviews) and E2 Empirical, each developed on sub-categories according to different related research methods. The Empirical attribute is further sub-categorized within three sub-categories. E2.1 Qualitative includes articles using as main methods case studies, interviews or content analysis with a qualitative approach. E2.2 Quantitative includes studies using a quantitative methodology, such as statistical methods, surveys, content analysis or mixed quantitative methods. E2.3. Multiple includes articles employing both qualitative and quantitative methods. The Research method criterion used by Dumay et al. (2016) has the disadvantage of a multiple methodology identification used in the literature. Guthrie et al. (2012) outlines that a part of their selected articles proved to be quite hard to classify under a certain attribute, as two or three research methods had been used. The Research method 
criterion is relevant, as it provides a more precise representation of the methodology adopted. Therefore, a secondary analysis based on the research methods is carried out to identify the trends in integrated reporting research methodology.

The Focus of Integrated Reporting (IR) literature (F) criterion, previously used by Guthrie et al. (2012) and Dumay et al. (2016) is composed of six attributes: F1 External reporting, F2 Auditing and assurance, F3 Accountability and governance F4 Management control/Strategy, F5 Performance measurement and F10 Other (including general). Nevertheless, along with the codding process, new attributes were developed, as new focus in integrated reporting research were identified. Using the four new attributes (F6 IR in practice - general, F7 Value creation/Business Model, F8 Integrated thinking/Capitals, F9 IR Determinants/benefits) a more adequate representation of the diverse themes covered by the most recent research may be brought to readers' attention.

The criterion Approaches to integrated reporting $(\mathrm{G})$ is developed from Dumay et al. (2016) by adding to the original attributes G1 King Report on Governance (IRC South Africa), G2 One Report, G3 IIRC pre-2013 Guidelines, and G4 IIRC 2013 Guidelines, two new attributes G5 GRI Framework and G6 Multiple frameworks. This change was decided as consequence of our initial content analysis and coding process on the six articles. We were observed that a number of articles (especially those published in the pre-IR Framework period) refer to the GRI standards as a start in their review of the integrated reporting. Moreover, it was noticed that a significant part of the articles refers to multiple Frameworks. This trend is also noticed by Dumay et al. (2016:175): "some authors use the term < IR $>$ synonymously to describe what we identify as different IR approaches".

Advancing within the frameworks' related analysis, the IR Frameworks, models, instruments $(\mathrm{H})$ criterion is considered with the focus on possible conceptual development of IR in the future. Authors as Dumay et al. (2016), Dumay and Garanina (2013) and Guthrie et al. (2012) also included this criterion in their research. The attributes included in this category are: None proposed (H1), Applies or considers previous (H2) and Proposes a new (H3). 


\subsection{Developing literature review reliability}

The SLR method applied in this study combined a content analysis of the articles' content with an articles' coding process, carried out manually. As Guthrie et al. (2012) argue, the manual coding benefit resides in the use of the implicit knowledge of the researcher for an effective interpretation of metaphorical text or complex information. In order to validate the analytical framework as well as the obtained results, several discussions were held within the research team, after the initial coding of the six articles. Consequently, the criteria and attributes that composed the analytical framework have been established and the coding difficulties were solved. Next, the entire database of articles was analyzed and coded by one of the authors. Content analysis and coding process were doubled by the other three authors using group discussion and critical thinking analysis in those cases where divergent codes were found. Finally, a check of the results was undertaken by the research team to identify any coding errors or discrepancies. The final values of each attribute were recorded, sorted and filtered using Excel spreadsheets.

\section{Findings}

\subsection{Characteristics of integrated reporting research during 2010-2017}

As evidenced in Table 2A, 59.7\% of the selected articles are published in journals indexed in the 'Business, Finance' category, followed by 'Management' (19.4\%) and 'Business' (11.1\%). Based on the number of published articles on integrated reporting, the Accounting, Auditing \& Accountability Journal is the most active publication in spreading the awareness related to this new research field, with 9 articles published. The special issue from 2014 (Vol. 27, Issue 7) has significantly contributed in introducing the integrated reporting theme into the mainstream literature, with 6 articles, representing 54.5\% of the articles published in IR area that year. Other journals interested in publishing integrated reporting articles are the Journal of Intellectual Capital with $11.1 \%$ of the sampled articles, followed by Sustainability Accounting, Management and Policy Journal and Critical Perspectives on Accounting with $8.3 \%$ of the sampled articles each. 
Table 2A. Article Distribution across Academic Journals

\begin{tabular}{|c|c|c|}
\hline Category & Total & $\%$ \\
\hline BUSINESS, FINANCE & 43 & $59.7 \%$ \\
\hline - Abacus & 1 & $1.4 \%$ \\
\hline - Accounting and Business Research & 2 & $2.8 \%$ \\
\hline - Accounting and Finance & 1 & $1.4 \%$ \\
\hline - Accounting, Auditing \& Accountability Journal & 9 & $12.5 \%$ \\
\hline - Accounting Horizons & 1 & $1.4 \%$ \\
\hline - Accounting, Organizations and Society & 1 & $1.4 \%$ \\
\hline - Australian Accounting Review & 4 & $5.6 \%$ \\
\hline - British Accounting Review & 4 & $5.6 \%$ \\
\hline - Critical Perspectives on Accounting & 6 & $8.3 \%$ \\
\hline - European Accounting Review & 1 & $1.4 \%$ \\
\hline - Journal of Accounting and Public Policy & 2 & $2.8 \%$ \\
\hline - Journal of International Financial Management \& Accounting & 1 & $1.4 \%$ \\
\hline - Managerial Auditing Journal & 4 & $5.6 \%$ \\
\hline - Sustainability Accounting, Management and Policy Journal & 6 & $8.3 \%$ \\
\hline MANAGEMENT & 14 & $19.4 \%$ \\
\hline - Business Strategy and the Environment & 2 & $2.8 \%$ \\
\hline - Corporate Social Responsibility and Environmental Management & 3 & $4.2 \%$ \\
\hline - Journal of Intellectual Capital & 8 & $11.1 \%$ \\
\hline - South African Journal of Economic and Management Sciences & 1 & $1.4 \%$ \\
\hline BUSINESS & 8 & $11.1 \%$ \\
\hline - Business Ethics: A European Review & 1 & $1.4 \%$ \\
\hline - Business Horizons & 1 & $1.4 \%$ \\
\hline - International Business Review & 2 & $2.8 \%$ \\
\hline - Journal of Business Ethics & 3 & $4.2 \%$ \\
\hline - Public Relations Review & 1 & $1.4 \%$ \\
\hline $\begin{array}{l}\text { ENGINEERING, ENVIRONMENTAL } \\
\text { - Journal of Cleaner Production }\end{array}$ & $\begin{array}{l}5 \\
5\end{array}$ & $\begin{array}{r}6.9 \% \\
6.9 \%\end{array}$ \\
\hline ECONOMICS & 2 & $2.8 \%$ \\
\hline - Amfiteatru Economic & 1 & $1.4 \%$ \\
\hline - Ecological Economics & 1 & $1.4 \%$ \\
\hline Total & 72 & $100 \%$ \\
\hline
\end{tabular}


Table 2B. The Evolution of Integrated Reporting research (2010-2017)

\begin{tabular}{lcccc}
\hline Year of publication & Total & $\boldsymbol{\%}$ & $\begin{array}{c}\text { Accounting } \\
\text { and Audit }\end{array}$ & $\%$ \\
\hline $\mathbf{2 0 1 0}$ & 0 & $0 \%$ & 0 & $0 \%$ \\
$\mathbf{2 0 1 1}$ & 1 & $1 \%$ & 1 & $1 \%$ \\
$\mathbf{2 0 1 2}$ & 2 & $3 \%$ & 1 & $1 \%$ \\
$\mathbf{2 0 1 3}$ & 4 & $6 \%$ & 1 & $1 \%$ \\
$\mathbf{2 0 1 4}$ & 11 & $15 \%$ & 7 & $10 \%$ \\
$\mathbf{2 0 1 5}$ & 16 & $22 \%$ & 11 & $15 \%$ \\
$\mathbf{2 0 1 6}$ & 15 & $21 \%$ & 7 & $10 \%$ \\
$\mathbf{2 0 1 7}$ & 23 & $32 \%$ & 14 & $19 \%$ \\
\hline Total & $\mathbf{7 2}$ & $\mathbf{1 0 0 \%}$ & $\mathbf{4 2}$ & $\mathbf{5 8 \%}$ \\
\hline
\end{tabular}

To respond the first research question RQ1. How have the integrated reporting field developed in recent years?, a detailed analysis is performed for the entire database of articles and also for the articles published in accounting and audit journals (Table 2B). The rise of interest in the integrated reporting research area has been fast and relatively recent (Table 2B), 75\% of the articles being published during the last three years. The accounting and audit journals are noted to have greatly contributed to the IR literature development, during the starting phase of the process (2010-2014) with 10 of 18 articles published and continuing along the second stage (2015-2017) with 32 articles of 54. In recent years, journals published in other area, such as Management, have begun to focus on this new reporting paradigm, since integrating reporting provides not only a disclosure framework but also a strategic tool - the integrated thinking (IIRC, 2013b).

\subsection{Changing in IR research paradigm}

It is of a great importance to include in analysis the articles' impact as it serves as a proxy for its quality, since not all articles have the same academic significance. To measure the article impact, Massaro et al. (2016) conclude that citations may be used to recognize whether an article is relevant for academic literature and to identify its influence on the academic debate.

For measuring the article impact, the Clarivate Analytics' Web of Science Citation Report is accessed. As Dumay and Dai (2014: 270 cited by Dumay et al., 2016).) state, "one problem with determining the impact from citations alone is that older articles can accumulate more citations". To overcome this constraint, two rankings 
included in Citation Report are used: top ten articles by total citations (Table 3) and top ten articles by average citation per year (Table 4).

Table 3. Top ten articles by total citations

\begin{tabular}{|c|c|c|c|c|}
\hline No. & Title & Authors & $\begin{array}{l}\text { Publicatio } \\
\text { n Year }\end{array}$ & $\begin{array}{c}\text { Total } \\
\text { Citations }\end{array}$ \\
\hline 1 & $\begin{array}{l}\text { Integrated Reporting: Insights, gaps and } \\
\text { an agenda for future research }\end{array}$ & $\begin{array}{l}\text { De Villiers } e t \\
\text { al. }\end{array}$ & 2014 & 75 \\
\hline 2 & $\begin{array}{l}\text { The Role of the Board in the } \\
\text { Dissemination of Integrated Corporate } \\
\text { Social Reporting }\end{array}$ & $\begin{array}{l}\text { Frias- } \\
\text { Aceituno et } \\
\text { al. }\end{array}$ & $2013 a$ & 71 \\
\hline 3 & $\begin{array}{l}\text { Integrated Reporting: An Opportunity for } \\
\text { Australia's Not-for-Profit Sector }\end{array}$ & $\begin{array}{l}\text { Adams and } \\
\text { Simnett. }\end{array}$ & 2011 & 49 \\
\hline 4 & $\begin{array}{l}\text { Is integrated reporting determined by a } \\
\text { country's legal system? An exploratory } \\
\text { study }\end{array}$ & $\begin{array}{l}\text { Frias- } \\
\text { Aceituno et } \\
\text { al. }\end{array}$ & $2013 b$ & 48 \\
\hline 5 & $\begin{array}{l}\text { The International Integrated Reporting } \\
\text { Council: A story of failure }\end{array}$ & Flower & 2015 & 47 \\
\hline 6 & $\begin{array}{l}\text { Integrated Reporting and internal } \\
\text { mechanisms of change }\end{array}$ & $\begin{array}{l}\text { Stubbs and } \\
\text { Higgins }\end{array}$ & 2014 & 46 \\
\hline 7 & $\begin{array}{l}\text { Integrated reporting: On the need for } \\
\text { broadening out and opening up }\end{array}$ & $\begin{array}{l}\text { Brown and } \\
\text { Dillard }\end{array}$ & 2014 & 45 \\
\hline 8 & $\begin{array}{l}\text { The International Integrated Reporting } \\
\text { Framework: Key Issues and Future } \\
\text { Research Opportunities }\end{array}$ & Cheng et al. & 2014 & 43 \\
\hline 9 & $\begin{array}{l}\text { The cultural system and integrated } \\
\text { reporting }\end{array}$ & $\begin{array}{l}\text { Garcia- } \\
\text { Sanchez et al. }\end{array}$ & 2013 & 41 \\
\hline 10 & $\begin{array}{l}\text { The International Integrated Reporting } \\
\text { Council: A call to action }\end{array}$ & Adams & 2015 & 41 \\
\hline
\end{tabular}

(Source: Clarivate Analytics' Web of Science Citation Report, accessed at 13.03.2018.)

The average citation per year became a proxy index for the impact of integrated reporting area in accounting research. This approach is also used by Dumay et al. (2016) and recommended by Massaro et al. (2016).

According to the Tables 3 and 4, there are eight articles common to both rankings, all published during 2013-2015. The first ten articles by total citations were cited by more than 40 articles, up to 75 articles (for De Villiers et al., 2014). Contrary to the "strong interest among scholars to cite the latest IR research", asserted by Dumay et al. (2016:170), our extended review shows that the articles published during the most recent two years couldn't enter the top ten articles by citation nor by average citation per year. Nevertheless, the paper of De Villiers et al. (2014) has the highest impact on integrated reporting research field, as it has been cited 75 times since it was published, with an average citation of 15 per year. 
Table 4. Top ten articles by citation per year

\begin{tabular}{|c|c|c|c|c|}
\hline No. & Title & Authors & $\begin{array}{l}\text { Publicati } \\
\text { on Year }\end{array}$ & $\begin{array}{l}\text { Average } \\
\text { per Year }\end{array}$ \\
\hline 1 & $\begin{array}{l}\text { Integrated Reporting: Insights, gaps and an agenda } \\
\text { for future research }\end{array}$ & $\begin{array}{l}\text { De Villiers } \\
\text { et al. }\end{array}$ & 2014 & 15 \\
\hline 2 & $\begin{array}{l}\text { The Role of the Board in the Dissemination of } \\
\text { Integrated Corporate Social Reporting }\end{array}$ & $\begin{array}{l}\text { Frias- } \\
\text { Aceituno } \\
\text { et al. }\end{array}$ & $2013 a$ & 11.83 \\
\hline 3 & $\begin{array}{l}\text { The International Integrated Reporting Council: A } \\
\text { story of failure }\end{array}$ & Flower & 2015 & 11.75 \\
\hline 4 & $\begin{array}{l}\text { The International Integrated Reporting Council: A } \\
\text { call to action }\end{array}$ & Adams & 2015 & 10.25 \\
\hline 5 & $\begin{array}{l}\text { Integrated Reporting and internal mechanisms of } \\
\text { change }\end{array}$ & $\begin{array}{l}\text { Stubbs and } \\
\text { Higgins }\end{array}$ & 2014 & 9.2 \\
\hline 6 & $\begin{array}{l}\text { Integrated reporting: On the need for broadening } \\
\text { out and opening up }\end{array}$ & $\begin{array}{l}\text { Brown and } \\
\text { Dillard }\end{array}$ & 2014 & 9 \\
\hline 7 & $\begin{array}{l}\text { The International Integrated Reporting } \\
\text { Framework: Key Issues and Future Research } \\
\text { Opportunities }\end{array}$ & $\begin{array}{l}\text { Cheng et } \\
\text { al. }\end{array}$ & 2014 & 8.6 \\
\hline 8 & $\begin{array}{l}\text { Is integrated reporting determined by a country's } \\
\text { legal system? An exploratory study }\end{array}$ & $\begin{array}{l}\text { Frias- } \\
\text { Aceituno } \\
\text { et al. }\end{array}$ & $2013 b$ & 8 \\
\hline 9 & $\begin{array}{l}\text { Walking the talk }(\mathrm{s}) \text { : Organisational narratives of } \\
\text { integrated reporting }\end{array}$ & $\begin{array}{l}\text { Higgins et } \\
\text { al. }\end{array}$ & 2014 & 7.6 \\
\hline 10 & $\begin{array}{l}\text { Explanatory Factors of Integrated Sustainability } \\
\text { and Financial Reporting }\end{array}$ & $\begin{array}{l}\text { Frias- } \\
\text { Aceituno } \\
\text { et al. }\end{array}$ & 2014 & 7.2 \\
\hline
\end{tabular}

(Source: Clarivate Analytics' Web of Science Citation Report, accessed at 13.03.2018.)

As evidenced in Table 4, articles published during 2013-2015 only are included in the top ten average citation per year ranking, while more recent articles haven't managed to receive enough citations in order to be included in the top ten most cited articles. An explanation for this may be the changing of the literature focus. These findings respond to the second research question RQ2. How and why is the research field changing?, especially when the two publishing phases are considered.

If the main objective of the articles published between 2013 and 2015 was to spread awareness regarding the new reporting paradigm, the most recent articles focus on studying the integrated reporting as a reporting practice. Additionally, as the diversity of IR research increased over the time, the authors publishing articles during the last two years have the tendency to refer to the most recognized articles, rather than to articles analyzing particular integrated reporting features.

The most relevant journal in terms of articles published in IR research field remains Accounting, Auditing \& Accountability Journal (AAAJ), as Dumay et al. (2016) previously observed. Four articles from 2014 AAAJ Special Issue appear in both rankings (Brown \& Dillard, 2014; De Villiers et al., 2014; Higgins et al., 2014; 
Stubbs \& Higgins, 2014). This indicates a significant impact on the academic debate conducted in terms of integrated reporting.

\subsection{Meta-analysis}

This sub-section provides a meta-analysis of the sampled articles and sets out to offer insights on recent developments of integrated reporting mainstream literature. Dumay et al. (2016) state that the integrated reporting literature did not pass the "first stage" of research (as off their cut-off date for paper search, 1 March 2015). Details for the second research question are next addressed to map and assess the evolution of integrated reporting research. The specific contribution would be to establish whether this field moved from a rising awareness phase to an impact analysis phase. The study follows the SLR method, coding the articles according to the analytical framework developed in Section 3.3 of this paper. The following illustrates the SLR's results, providing examples from the literature and developing insights based on this process.

\section{A. Jurisdiction}

The results in Table 5 show that $60 \%$ of the articles indicated a Supranational/International perspective in their endeavor of approaching the integrated reporting. These suggest a broadening of the researchers' interests in approaching the international aspects characterizing integrated reporting rather than the particular or country-specific level. This evolution was expected, as the IIRC strives to ensure a broad universal adoption of the integrated reporting practice (De Villiers et al., 2014) and this new reporting paradigm has attracted global academic and profession's attention.

Table 5. Jurisdiction

\begin{tabular}{|c|c|c|c|c|c|}
\hline & Jurisdiction & $\begin{array}{l}\text { No of } \\
\text { articles }\end{array}$ & Frequency & $\begin{array}{l}2010- \\
2014\end{array}$ & $\begin{array}{l}2015- \\
2017\end{array}$ \\
\hline A1 & Supra-national/International/Comparative & 43 & $60 \%$ & 10 & 33 \\
\hline A1.1 & $\begin{array}{l}\text { Supra-national/International/Comparative - } \\
\text { General }\end{array}$ & 22 & $31 \%$ & 6 & 16 \\
\hline A1.2 & $\begin{array}{l}\text { Supra-national/International/Comparative - } \\
\text { Industry }\end{array}$ & 2 & $3 \%$ & 0 & 2 \\
\hline A1.3 & $\begin{array}{l}\text { Supra-national/International/Comparative - } \\
\text { Organisational }\end{array}$ & 19 & $26 \%$ & 4 & 15 \\
\hline $\mathrm{A} 2$ & National & 25 & $35 \%$ & 8 & 17 \\
\hline$A 2.1$ & National - General & 1 & $1 \%$ & 1 & 0 \\
\hline$A 2.2$ & National - Industry & 0 & $0 \%$ & 0 & 0 \\
\hline$A 2.3$ & National - Organisational & 24 & $34 \%$ & 7 & 17 \\
\hline \multirow[t]{2}{*}{ A3 } & One Organisation & 4 & $5 \%$ & 0 & 4 \\
\hline & Total & 72 & $100 \%$ & 18 & 54 \\
\hline
\end{tabular}


In searching for a response to the RQ2.1 How global is the integrated reporting research and is there a shift in its perspective?, a shift of perspective is found. An interesting fact is that the research field seems to have moved from a General approach of integrated reporting towards an Organisational focus when the Dumay's et al. (2016) results are taken as reference. Thus, for the international approach, only half of the articles focus on organizations and industries, while 24 of 25 nationaloriented articles analyze specific organizations. Furthermore, Dumay et al. (2016) notice that the 2011-2014 integrated reporting literature mainly adopts a top-down approach trying to generalize findings for a larger group of companies as opposed to studying one organization's practice. The analysis in our paper, extending the publishing period up until November 2017, provides a similar trend, with only four articles of 72 focusing on a single organization (Beck et al., 2017; Lodhia, 2015; Mio et al., 2016; Veltri \& Silvestri, 2015;).

Overall, the number of articles analyzing integrated reporting with an Organisational perspective cover a significant percentage. Whether for international studies, both periods have similar numbers of articles covering General and Organisational focus, the national approach is more organizational-oriented. During the first stage of integrated reporting research, 2010-2014, the main objective could have been spreading awareness through publishing normative-oriented articles. Thus, 7 articles of 18 total articles published during this period have a General focus regarding the Jurisdiction (e.g. Adams \& Simett, 2011; Cheng et al., 2014). For the last three years (2015-2017), 36 articles have used an Organisational approach (e.g. Setia et al., 2015; Zhou et al., 2017) while only 16 articles analyzed the integrated reporting based on a top-down perspective (e.g. Humphrey et al., 2017; Lodhia \& Stone, 2017). Even so, the articles with a General focus published over the most recent three years have a critical perspective on integrated reporting or its fundamental concepts (e.g. De Villiers and Sharma, 2017; Humphrey et al., 2017).

\section{B. Organisational focus}

The global aspect of integrated research (RQ2.1) is supported by the findings on the extent of academic literature in terms of Organisational focus (Table 6). This section's results highlight that more than half of the reviewed articles conduct research on publicly listed entities (e.g. Buitendag et al., 2017; Haji \& Anifowose, 2017; Melloni, 2015). The percentage is higher than the Dumay's et al. (2016) and may explain the new focus of the latest IR Framework (IIRC, 2013a) towards the 'providers of financial capital'. 
Table 6. Organisational focus

\begin{tabular}{llcccc}
\hline Organisational focus & No of articles & Frequency & $\begin{array}{c}\mathbf{2 0 1 0}- \\
\mathbf{2 0 1 4}\end{array}$ & $\mathbf{2 0 1 5 - 2 0 1 7}$ \\
\hline B1 & Publicly listed & 39 & $54 \%$ & 9 & 30 \\
B2 & Private - SMEs & 0 & $0 \%$ & 0 & 0 \\
B3 & Private - Others & 8 & $11 \%$ & 2 & 6 \\
B4 & Public sector & 1 & $1 \%$ & 0 & 1 \\
B5 & Not-for-profit & 1 & $1 \%$ & 1 & 0 \\
B6 & General/Other & 23 & $32 \%$ & 6 & 17 \\
\hline & Total & $\mathbf{7 2}$ & $\mathbf{1 0 0 \%}$ & $\mathbf{1 8}$ & $\mathbf{5 4}$ \\
\hline
\end{tabular}

Only eight articles focus on analyzing the integrated reporting aspects through the lens of private companies (e.g. van Bommel, 2014; Lodhia, 2015), while none of the articles refers to SMEs. An insignificant attention is given to the public-sector (Veltri \& Silvestri, 2015) or not-for-profit organizations (Adams \& Simett, 2011). Distinctively analyzing the periods reflecting the two stages of research, the identified trend is comparable and no differentiation could be noticed.

The findings are consistent with those of Dumay et al. (2016), although the representativeness of articles with a general focus surpass that of the research on publicly listed. Thus, once more it may be argued that the IIRC's statement: "the framework is written primarily in the context of private sector" (IIRC, 2013b: 4) is a steady concern for academics. Even if the IIRC guidelines may be applied by notfor-profit and public-sector organizations, the research in this area has yet to rise.

\section{Location of research and authors' affiliation}

A specific contribution to research on integrated reporting in terms of its globalization (RQ2.1) is presented in Table 7. The most researched regions are South Africa with $13(18 \%)$ articles, followed by Australia with 7 (10\%) articles. Taking in consideration the analyzed sample, the specifics of the European Union, North America or Asia-Pacific haven't played an important role in integrated reporting research, so far, at least. Undoubtedly, the South African context is the leading location of research, as it represents a model for integrated reporting, with almost 24 years of experience in addressing critiques for alternatives to financial corporate reporting and with mandatory requirements for the JSE listed companies. 
Table 7. Location of research and authors' affiliation

\begin{tabular}{|c|c|c|c|c|c|}
\hline & & \multicolumn{2}{|c|}{ Location of research } & \multicolumn{2}{|c|}{ Authors' affiliation } \\
\hline & & No of articles & Frequency & $\begin{array}{l}\text { No of } \\
\text { articles }\end{array}$ & Frequency \\
\hline $\mathrm{C} 1$ & USA/Canada & 1 & $1 \%$ & 2 & $3 \%$ \\
\hline $\mathrm{C} 2$ & Australia & 7 & $10 \%$ & 13 & $18 \%$ \\
\hline $\mathrm{C} 3$ & United Kingdom & 3 & $4 \%$ & 8 & $11 \%$ \\
\hline $\mathrm{C} 4$ & European Union & 3 & $4 \%$ & 22 & $31 \%$ \\
\hline $\mathrm{C} 5$ & South Africa & 13 & $18 \%$ & 4 & $6 \%$ \\
\hline C6 & Asia-Pacific & 2 & $3 \%$ & 7 & $10 \%$ \\
\hline \multirow[t]{2}{*}{ C7 } & Other/Mixed & 43 & $60 \%$ & 16 & $22 \%$ \\
\hline & Total & 72 & $100 \%$ & 72 & $100 \%$ \\
\hline
\end{tabular}

Other locations of research that might have a significant contribution for this reporting system are the United Kingdom or the European Union, as the EU Directive specifically requires listed companies to consider the sustainability-related aspects when they report on their activity. The results are different as compared to Dumay's et al. (2016) findings. According to their results, the most active region is the European Union followed by Australia, while the South Africa takes the third place.

To support and validate the findings, Location of Research category is extended with Authors' affiliation (Table 7). The most interested authors in IR research are based in the European Union (22 articles) highlighting an increased interest in the context of adapting the European policies to IR requirements. However, only three articles are studying the integrated reporting practice of this region. A similar conclusion may be drawn in the case of the United Kingdom. From 8 research teams, not counting the mixed teams, only three articles focus on studying the UK's contribution in integrated reporting.

Irrespective authors' affiliation, the global aspect of the integrated reporting (RQ2.1) is preferred to be studied. Inspecting the C7 - Other/Mixed category, it is noted that 13 of 43 articles covering other areas than the first six listed in Table 7 are authored by mixed teams. Three other mixed teams contributed to research from South Africa (Barth et al., 2017; Bernardi \& Stark, 2016) and Australia (Higgins et al., 2014).

\section{Data sources}

Since a key challenge for integrated reporting research is access to data, an analysis on data sources used proves to be quite useful in answering the research question RQ2.2 What are the best research practices in integrated reporting. As outlined in Table 8, Author's primary data is one of the most frequent choice for data source, 
with 7 articles published between 2010-2014 and 15 articles published between 2015-2017. This type of source is mostly used when the authors gathered data for the specific purpose of the research, usually when interviewing experts or scholars (e.g. Chaidali \& Jones, 2017; Higgins et al., 2014) or when a survey is used (e.g. Ballou et al., 2012).

Table 8. Data sources

\begin{tabular}{llcccc}
\hline & \multicolumn{1}{c}{ Data Sources } & $\begin{array}{c}\text { No of } \\
\text { articles }\end{array}$ & Frequency & $\begin{array}{c}\mathbf{2 0 1 0}- \\
\mathbf{2 0 1 4}\end{array}$ & $\begin{array}{c}\mathbf{2 0 1 5}- \\
\mathbf{2 0 1 7}\end{array}$ \\
\hline D1 & $\begin{array}{l}\text { Corporate information } \\
\text { database/Corporate general ranking }\end{array}$ & 18 & $25 \%$ & 4 & 14 \\
D2 & Authors' primary data & 22 & $31 \%$ & 7 & 15 \\
D3 & Intergovernmental organization & 3 & $4 \%$ & 0 & 3 \\
D4 & Corporate website or internal data & 8 & $11 \%$ & 0 & 8 \\
D5 & Stock index & 1 & $1 \%$ & 0 & 1 \\
D6 & Mixed data sources & 1 & $1 \%$ & 0 & 1 \\
D7 & Other & 19 & $27 \%$ & 7 & 12 \\
\hline & Total & $\mathbf{7 2}$ & $\mathbf{1 0 0 \%}$ & $\mathbf{1 8}$ & $\mathbf{5 4}$ \\
\hline
\end{tabular}

The corporate information databases, such as Compustat, Thompson Reuters, GRI Database and Corporate ratings (the Forbes Global 2000 list) are the next widely used data sources, with 4 articles published between 2010-2014 and 14 articles published between 2015-2017 (Table 8). Other sources, such as Intergovernmental organization (the IIRC's Examples Database), Stock index (used by Garanina \& Dumay, 2017) and Corporate website or internal data are used only for the research conducted after 2015. The article of Mio et al. (2016) stands out as it uses three data sources (interview internal documents and field observations) for its case study on Generali's Internal Integrated Report. In the Other category are included conceptual articles and literature reviews which do not use particular data sources.

\section{E. Research methodology and research methods}

Table 9 shows the analysis of integrated reporting in terms of research methodology and research methods. There is a substantial and exponential increase of empirical studies in the second part of the period considered in analysis, while theoretical approach has a declining frequency starting with 2015. It is encouraging to see more empirical work in this area, as there have been many requests for these types of studies. Taking a closer look at the empirical category (qualitative, quantitative and mixed research methods listed in Table 9), it's noticed that qualitative and quantitative studies are comparable with around 20 studies per category. 
Table 9. Research methodology and research methods

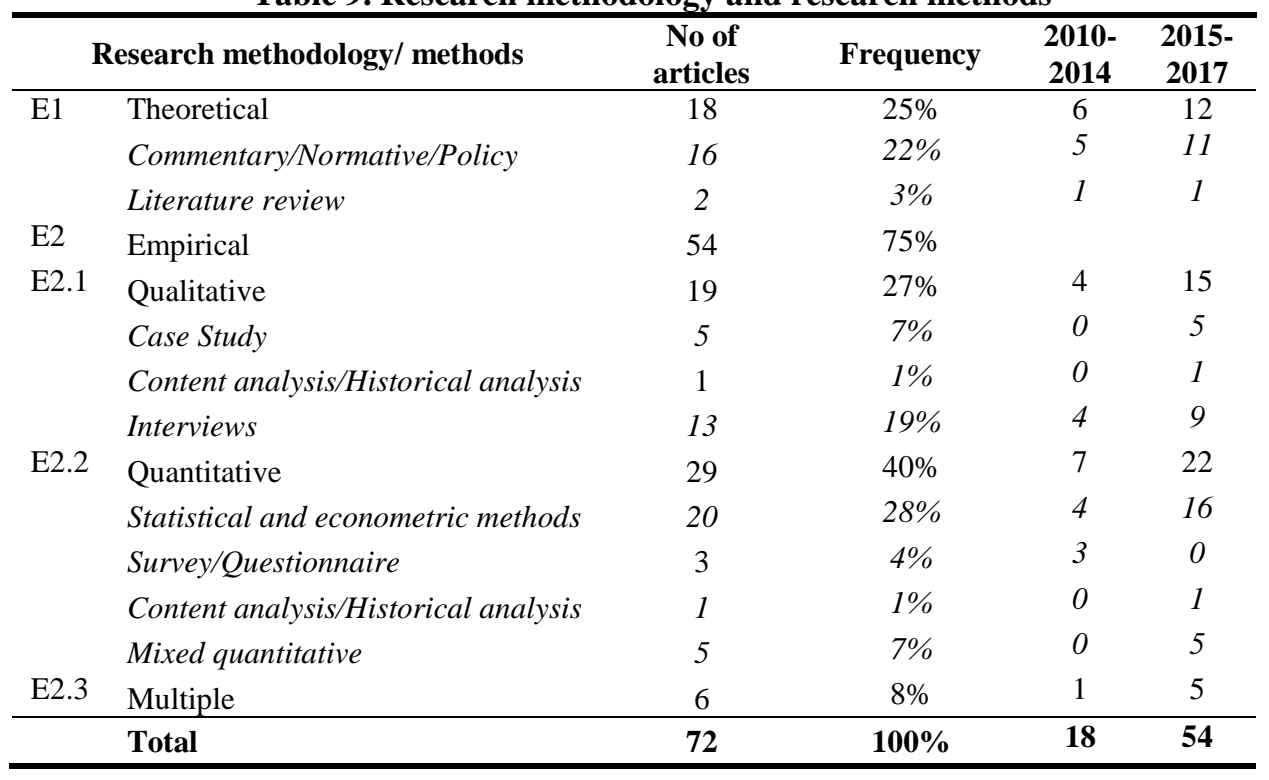

Detailing, the most commonly used are the statistical and econometrical methods and the time-analysis expose that there is an upward trend. Econometrical methods have been rarely used during the first stage of IR research (2011-2014 period), with only four articles (García-Sánchez et al., 2013; Frias-Aceituno et al., 2013a, b, 2014). Nevertheless, during 2015-2017, 16 articles using statistical and econometrical methods are published and their focus is mainly on performance measurement (e.g. Zhou et al., 2017) or integrated reporting determinants (e.g. García-Sánchez \& Noguera-Gámez, 2017).

The next most employed method after the Statistical and econometric category is Commentary/Normative/Policy, with 16 articles (22\%). This is consistent with Dumay et al. (2016) who note the increased importance of Commentary/Normative/Policy, the prevalent method during the 2011-2014 period. Similar to statistical and econometric methods, the number of normative articles increased in usage during the recent years. However, in terms of significance, the findings in Table 9 show a second place for the normative method.

\section{F. Focus of IR literature}

The current trends of IR literature are analyzed in order to find a possible connectivity between the criteria of IR frameworks and the focus of IR literature (RQ2.3). The findings show that the focus of IR literature mirrors the new trends in IR frameworks. 
Thus, Table 10 indicates the External Reporting/Sustainability Reporting to be the most active area of interest for the research field, with 23 articles (e.g. Ballou et al., 2012; Cheng et al., 2014; Lodhia \& Stone, 2017; Stacchezzini et al., 2016). These results are expected, considering the primary purpose of IR Framework: disclosing the long-term value creation process for external users of the company (IIRC, 2013b). They are also correlated with the findings of Dumay et al. (2016) noticing the same trend in their study. Likewise, an increasing number of authors claim that integrated reporting has the potential to change the existing corporate reporting practice, as it offers solutions to traditional accounting reporting criticism (Brown \& Dillard, 2014; De Villiers et al., 2017; Zhou et al., 2017).

Table 10. Focus of IR literature

\begin{tabular}{llcccc}
\hline & \multicolumn{1}{c}{ Focus of IR literature } & $\begin{array}{c}\text { No of } \\
\text { articles }\end{array}$ & Frequency & $\begin{array}{c}\mathbf{2 0 1 0}- \\
\mathbf{2 0 1 4}\end{array}$ & $\begin{array}{c}\mathbf{2 0 1 5}- \\
\mathbf{2 0 1 7}\end{array}$ \\
\hline F1 & External reporting/Sustainability reporting & 23 & $32 \%$ & 9 & 14 \\
F2 & Auditing and assurance & 4 & $6 \%$ & 0 & 4 \\
F3 & Accountability and governance & 1 & $1 \%$ & 1 & 0 \\
F4 & Management control/Strategy & 1 & $1 \%$ & 0 & 1 \\
F5 & Performance measurement & 6 & $8 \%$ & 0 & 6 \\
F6 & IR in practice - general aspects & 9 & $13 \%$ & 0 & 9 \\
F7 & Value creation/Business Model & 6 & $8 \%$ & 2 & 4 \\
F8 & Integrated thinking/Capitals & 6 & $8 \%$ & 1 & 5 \\
F9 & IR Determinants/benefits & 11 & $15 \%$ & 4 & 7 \\
F10 & Other (including general) & 5 & $7 \%$ & 1 & 4 \\
\hline & Total & $\mathbf{7 2}$ & $\mathbf{1 0 0 \%}$ & $\mathbf{1 8}$ & $\mathbf{5 4}$ \\
\hline
\end{tabular}

The second most important focus of the IR literature is analyzing the determinants or benefits of integrated reporting adoption. Although with a lower frequency (15\%) as compared to Dumay et al. (2016), this research path is approached by 11 articles. Detailing the analysis of the 11 articles on the balance between the articles addressing determinants and benefits of integrated reporting, there is a clear trend towards determinants. Most of the articles focus on studying the impact of industry concentration, company size, profitability, business sector, growth opportunities (Frias-Aceituno et al., 2014), cultural system (Garcia-Sanchez et al., 2013) or legal system influences (Frias-Aceituno et al., 2013b) on the development of integrated reporting.

Extending the characteristics of the Focus of IR literature attribute, we examine how integrated reporting is approached in the practice. The Dumay's et al. (2016:177) assertion "that $\langle\mathrm{IR}>$ is not simply accepted as the corporate reporting norm" characterizes the first stage of IR research. In the $2011-2014$ period the focus of 
literature was to popularize the emergent practice and no research on companies' practice using the concepts of integrated reporting was carried out. Moreover, our findings highlight nine articles (13\%), published between 2015 and 2017 analyzing general aspects of IR in practice. This aspect is a response to the many demands to study how the integrated reporting is translating in practice. Four articles (Burke \& Clark, 2016; Chaidali \& Jones, 2017; Perego et al., 2016; Robertson \& Samy, 2015) highlight the views of preparers, regulators and academics regarding integrated reporting. Another three articles (Beck et al., 2017; Lodhia, 2015; Veltri \& Silvestri, 2015;) study the integrated reporting through the lens of individual companies, and two other articles debate the case of multiple organizations at international (Adams et al., 2016) or national level (Haji \& Anifowose, 2017).

Other interesting focuses in the integrated reporting research field are Auditing and assurance (e.g. Maroun, 2017), Performance measurement (e.g. Garcia-Sanchez \& Noguera-Gamez, 2017; Zhou et al., 2017), Value creation and Business Model (e.g. Beattie \& Smith, 2013; Maniora, 2017) and Integrated thinking/ Capitals (e.g. Coulson et al., 2015; Garanina \& Dumay, 2017). Less approached study field of this domain are Accountability and governance and Management control/Strategy with only one paper each.

\section{G. Approaches to IR}

Dumay et al. (2016: 176) argue that "there is a lack of critical understanding among scholars about what integrated reporting is". In advancing this argument the RQ 2.3 research question is addressed to find the way the criteria of IR frameworks may be connected with the specific focus of IR literature. The results in Table 11 highlight that the majority of the authors (53\%) refer to integrated reporting approaches by citing multiple frameworks, as a way to properly document their research on integrated reporting.

Apart from citing multiple integrated reporting approaches, there are articles referring to a single framework. Frequently, the authors cited the IIRC's International Integrated Reporting Framework (e.g. van Bommel, 2014; Melloni, 2015) or the IIRC pre-2013 Guidelines (the 2011 Discussion Paper). Although South Africa is one of the most interesting research location, with many articles analyzing the integrated reporting practice of the JSE listed companies, only three articles strictly refer to guidelines proposed by King III or IRC of South Africa (e.g. Bernardi \& Stark, 2016; Buitendag et al., 2017; Setia et al., 2015). 
Table 11. Approaches to IR

\begin{tabular}{llcccc}
\hline \multicolumn{1}{c}{ Approaches to IR } & $\begin{array}{c}\text { No of } \\
\text { articles }\end{array}$ & Frequency & $\begin{array}{c}\mathbf{2 0 1 0}- \\
\mathbf{2 0 1 4}\end{array}$ & $\begin{array}{c}\mathbf{2 0 1 5}- \\
\mathbf{2 0 1 7}\end{array}$ \\
\hline G1 & King Report on Governance (IRC of & 3 & $4 \%$ & 0 & 3 \\
& South Africa) & & $0 \%$ & 0 & 0 \\
G2 & One Report & 0 & $17 \%$ & 5 & 7 \\
G3 & IIRC pre-2013 Guidelines & 12 & $26 \%$ & 2 & 17 \\
G4 & IIRC, 2013 Guidelines & 19 & $0 \%$ & - & 0 \\
G5 & GRI Framework & 0 & $53 \%$ & 11 & 27 \\
G6 & Multiple frameworks & 38 & $\mathbf{1 0 0 \%}$ & $\mathbf{1 8}$ & $\mathbf{5 4}$ \\
\hline
\end{tabular}

\section{Discussion and conclusion}

\subsection{Integrated reporting frameworks, models and instruments}

Building on the approaches to integrated reporting, the analysis of the frameworks, models and instruments referred to or proposed by the sampled articles is further discussed. The findings show that 64 of the total 72 articles consider previous frameworks (e.g. Baboukardos \& Rimmel, 2016; Coulson et al., 2015; Gunarathne $\&$ Senaratne, 2017). These findings are in line with those of Dumay et al. (2016) who state that integrated reporting is a new phenomenon and most authors accept previous highly recognized views of this reporting novelty.

However, this sub-section does not aim to establish the fact that all the articles refer to a specific framework or model, but to mainly discover the articles who bring innovations to the academic field. The results show that eight articles (Abeysekera, 2013; Alexander \& Blum, 2016; Atkins et al., 2015; Haller \& van Staden, 2014; Maroun, 2017; Maas et al., 2016; Oliver et al., 2016; Rambaud \& Richard, 2015) took a step forward and proposed frameworks or instruments meant to improve features of integrated reporting practice. As Dumay et al. (2016) outline, the main motivation to create a new instrument or framework resides in the need for the development of a significant literature in IR research, with the premises of building a foundation for IR future research.

Abeysekera engaged in framework proposition as early as 2013, when the IIRC's Framework was still under discussion. The articles aimed "to propose a template for integrated reporting in organizations" (Abeysekera, 2013: 227) being the first academic paper to do so. Continuing this trend, Haller and van Staden (2014) propose a 'value added statement' (VAS) which has the potential to serve as a practical and effective reporting instrument for integrated reporting. Another interesting suggestion is made by Maroun (2017) who developed three possible integrated reporting assurance models, based on existing assurance principles 
combined with views of 20 audit experts and 20 preparers. The interest of proposing new frameworks and models for integrated reporting shows that this research field is maturing and becoming recognized as a discipline within accounting research.

\subsection{Future research}

The future research perspectives are the main driver for the integrated reporting impact on the literature. Recommendations on research related to voluntary disclosure literature and the voluntary and the mandatory IFRS adoption literature, may also be applied to IR research (De Villiers et al., 2017). Humphrey et al. (2017) advances this idea by discussing the role of IIRC in delivering a fundamental repositioning of the corporate reporting configuration through participative involvement of various groups of stakeholders. Investigations on possible perspectives of integrated reporting are proposed by Chaidalia and Jones (2017) taking into account the central role of collaboration between IR developers and its users. Meanwhile, Lodhia and Stone (2017) see an increased impact of integrated reporting practice when the potential of internet and social media technologies is valorized.

Gunarathne and Senaratne (2017: 541-542) state that it is interesting to study integrated reporting in different locations or industries as "the cultural impact of new managerial technologies" can enhance "the understanding of the global picture of accounting". This idea, corroborated with the IR framework's emphasis (IIRC, 2013b) on disclosing how an entity's strategy is reflected in its business model, may be addressed in future research on integrated thinking. The future approaches of IIRC are brought to attention by Humphrey et al. (2017) in terms of focus and trends of integrated reporting practices. They conclude that companies' choices of supporting, eliminating or ignoring the integrated reporting along with the level of their understanding the significance of integrated reporting might complement the standards setters' initiatives and efforts. Feng et al. (2017) also highlight the lack of practitioners' understanding that discourages the IR adoption in practice.

Tweedie et al. (2017), building on Eccles et al. (2015), suggest practitioner-focused research on integrated reporting business model aiming the development of conceptual and practical tools. Likewise, Melloni et al. (2017) draw a signal on the decision of whether a mandatory IR reporting is preferable over a voluntary corporate reporting. Further research on associations between dominance of management impression and possible improvements of corporate reporting may respond to the question whether companies could achieve "a better combination of conciseness and completeness in reports" (Melloni et al., 2017: 235). This may generate opportunities for changing the managers and boards of directors' views on the long-term prospects of their business. Hence, the IIRC envisages that the process of preparing an integrated report will affect managers' internal decisions by directing them to focus more on the firm's long-term sustainability than on its short-term financial performance (De Villiers et al., 2017). 
Future research might bring to discussion possible links between integrated reporting, governance and integrated thinking. The complex interrelationships influencing the companies' ability to create value for the multi-stakeholders is already referred to in practice as 'integrated thinking'. Adams (2017) finds out that a broader view of value creation applied to contemporary reporting processes may influence the managers' sights and assist the decision-making process. The change in corporate reporting trend from disclosing the impacts towards focusing on the value creation addressed by the developments of IIRC Framework may result in influencing the mindset of corporate leaders and in emergence of new reporting practices (Adams, 2017).

Capital markets and real effects are found in Barth et al. (2017) to be the generating elements for promoting corporate integrated thinking and improving integrated reporting quality. However, the authors suggest a group effort of managers, practitioners, standard-setters, regulators, and investors in contributing to the process of integrated reporting globalization. Nevertheless, Maroun's (2017) insights and recommendations on the assurance of integrated reporting are not to be ignored in future research. By including the views of different stakeholders (institutional investors, analysts and international standard-setters) on possible assurance models, Maroun (2017) argue that the IR Framework may be extended in terms of materiality, associated risks and specific assurance procedures.

In conclusion, the findings of this research suggest an evolution of integrated reporting research towards the second stage identified by Dumay et al. (2016). We evidenced the movement to an impact analysis phase and the extending research of IR in practice.

\section{Acknowledgements}

We appreciate the helpful comments and the constructive suggestions on previous drafts of this study presented at 13th edition of the International Conference Accounting and Management Information Systems (AMIS 2018), Bucharest, Romania. Special thanks are addressed to anonymous reviewers of this journal, for insightful recommendations.

\section{References}

Abeysekera, I. (2013) “A template for integrated reporting", Journal of Intellectual Capital, vol. 14, no. 2: 227-245

Adams, C. (2017) "Conceptualising the contemporary corporate value creation processes", Accounting, Auditing and Accountability Journal, vol.30, no. 4: 906-931 
Adams, C.A., Potter, B., Singh, P.J. \& York, J. (2016) "Exploring the implications of integrated reporting for social investment (disclosures)", The British Accounting Review, vol. 48: 283-296

Adams, S. \& Simmet, R. (2011) "Integrated Reporting: An Opportunity for Australia's Non-for-Profit Sector", Australian Accounting Review, vol. 21, no. 3: 292-301

Alexander, D. \& Blum, V. (2016) "Ecological economics: A Luhmannian analysis of integrated reporting", Ecological Economics, vol. 129: 241-251

Atkins, J., Atkins, B.C., Thomson, I. \& Maroun, W (2015) ""Good" news from nowhere: imagining utopian sustainable accounting' Accounting", Auditing \& Accountability Journal, vol. 28, no. 5: 651-670

Baboukardos, D. \& Rimmel, G. (2016) "Value relevance of accounting information under an integrated reporting approach: A research note", Journal of Accounting Public Policy, vol. 35: 437-452

Ballou, B., Casey, R.J., Grenier, J.H. \& Heitger, D.L. (2012) "Exploring the Strategic Integration of Sustainability Initiatives: Opportunities for Accounting Research", Accounting Horizons, vol.26, no.2: 265-288

Barth, M.E, Cahan, S.F, Chen, L. \& Venter, E.R. (2017) "The economic consequences associated with integrated report quality: Capital market and real effects", Accounting, Organizations and Society, vol. 62: 43-64

Beattie, V. \& Smith, S.J. (2013) "Value creation and business models: Refocusing the intellectual capital debate", The British Accounting Review, vol. 45: 243-254

Beck, C., Dumay, J. \& Frost, G. (2017) "In Pursuit of a "Single Source of Thrust": from Threatened Legitimacy to Integrated Reporting", Journal of Business Ethics, vol. 141: 191-205

Bernardi, C. \& Stark, A.W, (2016) "Environmental, social and governance disclosure, integrated reporting, and the accuracy of analysts' forecasts", The British Accounting Review, vol. 50: 16-31

Broadbent, J. \& Guthrie, J. (2008) "Public sector to public services: 20 years of "contextual" accounting research", Accounting, Auditing \& Accountability Journal, vol. 21, no. 2: 129-169

Brown, J. \& Dillard, J. (2014) "Integrated reporting: On the need for broadening out and opening up", Accounting, Auditing \&Accountability Journal, vol. 27, no. 7: $1120-1156$

Buhr, N., Gray, R. \& Milne, M. J. (2014) Histories, rationales, voluntary standards and future prospects for sustainability reporting in: Bebbington, J., Unerman, J. \& O'Dwyer, B. Sustainability Accounting and Accountability, $2^{\text {nd }}$ ed. London: Routledge

Buitendag, N., Fortuin, G.S. \& de Laan, A. (2017) „Firm characteristics and excellence in integrated reporting", South African Journal of Economic and Management Sciences, vol. 20, no. 1: 1-8

Burke, J.J. \& Clark, C.E. (2016) "The business case for integrated reporting: Insights from leading practitioners, regulators, and academics", Business Horizons, vol. 59: 273-283 
Caraiani, C., Lungu, C.I., Dascălu, C. \& Colceag, F. (2015) Green Accounting Initiatives and Strategies for Sustainable Development, IGI Global, Idea Group Publishing

Chaidali, P. \& Jones, M.J. (2017) "It's a matter of trust: Exploring the perceptions of Integrated Reporting preparers", Critical Perspectives on Accounting, vol. $48(\mathrm{C}): 1-20$

Cheng, M., Green, W., Conradie, P., Konishi, N. \& Romi, A. (2014) "The International Integrated Reporting Framework: Key Issues and Future Research Opportunities", Journal of International Financial Management \& Accounting, Vol. 25, no. 1: 90-119

Coulson, A.B., Adams, C.A., Nugent, M.N. \& Haynes, K. (2015) "Exploring metaphors of capitals and the framing of multiple capitals: Challenges and opportunities for $<$ IR $>$ ", Sustainability Accounting, Management and Policy Journal, vol. 6, no. 3: 290-314

Denyer, D. \& Tranfield, D. (2006) "Using qualitative research synthesis to build an actionable knowledge base", Management Decision, vol. 44, no. 2: 213-227

De Villiers, C., Rinaldi, L. \& Unerman, J. (2014) "Integrated Reporting: Insights, gaps and an agenda for future research", Accounting, Auditing \& Accountability Journal, vol. 27, no.7: 1042-1067

De Villiers, C., Venter, E.R. \& Hsiao, P.C.K. (2017) "Integrated reporting: background, measurement issues, approaches and an agenda for future research", Accounting \& Finance, vol. 54, no. 8: 937-959

De Villiers, C. \& Sharma, U. (2017) "A critical reflection on the future of financial, intellectual capital, sustainability and integrated reporting", Critical Perspectives on Accounting, forthcoming, available on-line at: https://www.researchgate.net/publication/317019424_A_critical_reflection_ on_the_future_of_financial_intellectual_capital_sustainability_and_integrate d_reporting, accessed 12.02.2018

Dumay, J., Bernardi, C., Guthrie, J. \& Demartini, P. (2016) "Integrated reporting: A structured literature review", Accounting Forum, vol. 40: 166-185

Dumay, J. \& Garanina, T. (2013) "Intellectual capital research: a critical examination of the third stage", Journal of Intellectual Capital, vol. 14, no. 1: 10-25

Eccles, R.G. \& Krzus M.P. (2015) The Integrated Reporting Movement: Meaning, Momentum, Motives, and Materiality, Hoboken, New Jersey: John Wiley \& Sons

Eccles, R.G. \& Krzus, M.P. (2010). One Report: Integrated Reporting for a Sustainable Strategy, John Wiley \& Sons

Feng, T., Cummings, L. \& Tweedie, D. (2017) "Exploring integrated thinking in integrated reporting - an exploratory study in Australia", Journal of Intellectual Capital, vol. 18, no. 2: 330-353

Flower, J. (2015) "The International Integrated Reporting Council: A story of failure", Critical Perspectives on Accounting, vol.27: 1-17

Frias-Aceituno, J.V., Rodriguez-Ariza, L. \& Garcia-Sanchez, I.M. (2014) "Explanatory factors of integrated sustainability and financial reporting", Business Strategy and the Environment, vol.23: 56-72 
Frias-Aceituno, J.V., Rodriguez-Ariza, L. \& Garcia-Sanchez, I.M. (2013a) "The role of the board in the dissemination of integrated corporate social reporting", Corporate Social Responsibility and Environmental Management, vol. 20: 219-233

Frias-Aceituno, J.V., Rodriguez-Ariza, L. \& Garcia-Sanchez, I.M. (2013b) "Is integrated reporting determined by a country's legal system? An exploratory study", Journal of Cleaner Production, vol. 44: 45-55

Garanina, T. \& Dumay, J. (2017) "Forward-looking intellectual capital disclosure in IPOs Implications for intellectual capital and integrated reporting “, Journal of Intellectual Capital, vol. 18 no. 1: 128-148

Gunarathne, N. \& Senaratne, S. (2017) "Diffusion of integrated reporting in an emerging South Asian (SAARC) nation", Managerial Auditing Journal, vol. 32, no. 4/5, 2017: 524-548

Garcia-Sánchez, I.M. \& Noguera-Gámez, L. (2017) "Integrated information and the cost of capital", International Business Review, vol. 26: 959-975

Garcia-Sánchez, I.M., Rodriguez-Ariza, L. \& Frias-Aceituno, J.V. (2013) "The cultural system and integrated reporting", International Business Review, vol. 22: 828-838

Guthrie, J., Ricceri, F. \& Dumay, J. (2012) "Reflections and projections: A decade of Intellectual Capital Accounting Research", The British Accounting Review, vol. 44: $68-82$

Haji, A.A. \& Anifowose, M. (2017) "Initial trends in corporate disclosures following the introduction of integrated reporting practice in South Africa", Journal of Intellectual Capital, vol. 18 no. 2: 373-399

Haller, A. \& van Staden, C. (2014) "The value-added statement - an appropriate instrument for Integrated Reporting", Accounting, Auditing \& Accountability Journal, vol. 27, no. 7: 1190-1216

Higgins, C. Stubbs, W. \& Love, T. (2014) "Walking the talk(s): Organizational narratives of integrated reporting", Accounting, Auditing \& Accountability Journal, vol. 27, no.7: 1090-1119

Humphrey, C., O’Dwyer, B. \& Unerman, J. (2017) “Re-theorizing the configuration of organizational fields: the IIRC and the pursuit of 'Enlightened' corporate reporting, Accounting and Business Research, vol. 47, no. 1: 30-63

International Integrated Reporting Committee (IIRC)(2013a) Consultation draft of the international <IR> framework, available on-line at: http://integrate dreporting.org/wp-content/uploads/2013/03/Consultation-Draft-of-theInternationalIRFramework.pdf, accessed 15.10.17

International Integrated Reporting Council (IIRC) (2013b) The international <IR> framework, available on-line at: http://integratedreporting.org/wpcontent/uploads/2013/12/13-12-08-THE-INTERNATIONAL-IR-

FRAMEWORK-2-1.pdf, accessed 15.10.17

Lodhia, S. (2015) "Exploring the transition to integrated reporting through a practice lens: An Australian customer owned bank perspective", Journal of Business Ethics, vol. 129: 585-598 
Lodhia, S. \& Stone, G. (2017) "Integrated Reporting in an internet and social media communication environment: conceptual insights", Australian Accounting Review, vol. 27, no. 1: 17-33

Lungu, C.I., Caraiani, C., Dascălu, C. \& Guşe, R.G. (2009) "Critical interpretation study of social and environmental aspects presented in accounting ISI journals", Accounting and Management Information, vol. 8, no. 3: 352-371

Lungu, C.I., Caraiani, C., Dascălu, C., Turcu, D.R. \& Turturea, M. (2016) “Archival analysis of Corporate Social Responsibility research: the Romanian perspective", Accounting and Management Information Systems, vol. 15, no. 2: $341-371$

Lungu, C.I., Caraiani, C. \& Dascălu, C., (2017) The materiality matrix - an emerging tool for sustainability performance disclosure, Proceedings of 12th International Conference Accounting and Management Information Systems: AMIS 2017, Bucharest, Romania

Maas, K., Schaltegger, S. \& Crutzen, N. (2016) "Integrating corporate sustainability assessment, management, accounting, control and reporting", Journal of Cleaner Production, vol. 136, Part A: 237-248

Maniora, J. (2017) "Is integrated reporting really the superior mechanism for the integration of ethics into the core business model? An empirical analysis", Journal of Business Ethics, vol. 140: 755-786

Maroun, W. (2017) "Assuring the integrated report: Insights and recommendations from auditors and preparers", The British Accounting Review, vol. 49: 329-346

Massaro, M., Dumay, J. \& Guthrie, J. (2016) "On the shoulders of giants: undertaking a structured literature review in accounting", Accounting, Auditing \& Accountability Journal, vol. 29, no. 5: 767-801

Melloni, G. (2015) "Intellectual Capital disclosure in integrated reporting: an impression management analysis", Journal of Intellectual Capital, vol. 16, no. 3: $661-680$

Melloni, G., Gaglio, A. \& Perego, P. (2017) "Saying more with less? Disclosure conciseness, completeness and balance in Integrated Reports", Journal of Accounting Public Policy, vol. 36: 220-238

Mio, C., Marco, F. \& Pauluzzo, R. (2016) "Internal application of IR principles: Generali's Internal Integrated Reporting", Journal of Cleaner Production, vol. 139: 204-2018

Oliver, J., Vesty, G. \& Brooks, A. (2016) "Conceptualizing integrated thinking in practice", Managerial Auditing Journal, vol. 31, no. 2: 228-248

Perego, P., Kenedy, S. \& Whiteman, G. (2016) "A lot of icing but little cake? Taking integrated reporting forward", Journal of Cleaner Production, vol. 136: 53-64

Petty, R. \& Guthrie, J. (2000) "Intellectual capital literature review: Measurement, reporting and management", Journal of Intellectual Capital, vol. 1, no. 2: $155-176$ 
Pisani, N., Kourula, A., Kolk, A. \& Meijer, R. (2017) "How global is international CSR research? Insights and recommendations from a systematic review", Journal of World Business, vol. 52: 591-614

Rambaud, A. \& Richard, J. (2015) "The "Triple Depreciation Line" instead of the "Triple Bottom Line": Towards a genuine integrated reporting", Critical Perspectives on Accounting, vol. 33: 92-116

Robertson, F.A. \& Samy, M. (2015) "Factors affecting the diffusion of integrated reporting - a UK FTSE 100 perspective", Sustainability Accounting, Management and Policy Journal, vol. 6, no. 2: 190-223

Setia, N., Abhayawansa, S., Joshi, M. \& Huinh, A.V. (2015) "Integrated reporting in South Africa: an initial evidence", Sustainability Accounting, Management and Policy Journal, vol. 6, no. 3: 397-424

Stacchezzini, R., Melloni, G. \& Lai, A. (2016) "Sustainability management and reporting: the role of integrated reporting for communicating corporate sustainability management", Journal of Cleaner Production, vol. 136: $102-110$

Stubbs, W. \& Higgins, C. (2014) "Integrated reporting and internal mechanisms of change", Accounting, Auditing \& Accountability Journal, vol. 27, no.7: 1068-1089

Tweedie, D., Nielsen, C. \& Martinov-Bennie, N. (2017) "The business model in integrated reporting: evaluating concept and application", Australian Accounting Review, doi: 10.1111/auar.12196: 1-16

van Bommel, K. (2014) "Towards a legitimate compromise?: An exploration of Integrated Reporting in the Netherlands", Accounting, Auditing \& Accountability Journal, vol. 27, no. 7: 1157-1189

Vaz, N., Fernandez-Feijoo, B. \& Ruiz, S. (2016) "Integrated reporting: an international overview", Business Ethics: A European Review, vol.25, no. 4: $577-591$

Velte, P. \& Stawinoga, M. (2017) "Integrated reporting: The current state of empirical research, limitations and future research implications", Journal of Management Control, vol. 28, no. 3: 275-320

Veltri, S. \& Silvestri, A. (2015) "The Free State University integrated reporting: a critical consideration”, Accounting, Auditing \& Accountability Journal, vol. 16, no. 2: 443-462

Zhou, S., Simnett, R. \& Green, W. (2017) "Does integrated reporting matter to the capital market?”, Abacus, vol. 53, no. 1: 94-132 